\title{
Rhipsalis grandiflora Haw. (CACTACEAE) PROPAGATION BY STEM CUTTINGS
}

\author{
Giulio Cesare Stancato ${ }^{1 *}$; Francismar Francisco Alves Aguiar ${ }^{2}$; Shoey Kanashiro ${ }^{2}$; Armando \\ Reis Tavares²; Eduardo Luís Martins Catharino²; Rosiris Bergemann de Aguiar Silveira² \\ ${ }^{1}$ IAC - Centro de Horticultura, C.P. 28 - 13001-970 - Campinas, SP - Brasil. \\ IBt - Centro de Pesquisas Horticulturais, C.P. 4005 - 01061-970 - São Paulo, SP - Brasil. \\ *Corresponding author <stancato@iac.sp.gov.br>
}

\begin{abstract}
The genus Rhipsalis is being cultivated as a potted plant since the view of the pendant branches with coloured flowers and fruit is very appreciated. Considering that there is no information about the production of rooted propagules of these species, the goal of this work was to evaluate the development of stem cuttings, stimulated by the application of plant growth regulators. The indolebutyric acid (IBA) was tested at $0 ; 4.07 ; 5.81$, and $11.63 \mathrm{mmol} \mathrm{L}^{-1}$ and the naphthaleneacetic acid (NAA) at $0 ; 4.53 ; 6.47$, and 12.94 $\mathrm{mmol} \mathrm{L} \mathrm{L}^{-1}$ for their activity in promoting roots on apical stem segments of Rhipsalis grandiflora Raw. The base of stem cuttings was dipped into auxin solutions mixed with talc and each one was partially embedded in fir bark (Pinus sp) and fern fiber (1:1) in polystyrene propagation flats, placed throughout the rooting period in a greenhouse (50\% shading), at 60-90\% of relative humidity and temperatures from 20 to $25^{\circ} \mathrm{C}$. The experimental design was a completely randomised with eight treatments (twelve replicates), with samplings at $0 ; 20 ; 50 ; 80$, and 150 days. The results indicate no differences between IBA and NAA regarding the dry mass of roots, but an increase in for concentrations of 0 and $4.07 \mathrm{mmol} \mathrm{L}^{-1}$ of IBA and 0 and $4.53 \mathrm{mmol} \mathrm{L}^{-1}$ of NAA, in relation to treatments with auxins. Stem cuttings treated with 4.07 mmol L $\mathrm{L}^{-1}$ of IBA and $4.53 \mathrm{mmol} \mathrm{L}^{-1}$ of NAA, had greater dry mass of shoot bud differentiation in relation to those treated with $0 \mathrm{mmol} \mathrm{L}^{-1}$.
\end{abstract}

Key words: Rhipsalidinae, articles, plant growth regulators

\section{PROPAGAÇÃO DE Rhipsalis grandiflora Haw. (CACTACEAE) POR ESTACAS}

\begin{abstract}
RESUMO: Plantas do gênero Rhipsalis estão sendo cada vez mais cultivadas em vaso, pois o efeito ornamental de seus ramos pendentes, com flores e frutos coloridos, é bastante apreciado. Em vista da falta de informações sobre o procedimento adotado para a formação de mudas, o objetivo deste trabalho foi de avaliar o desenvolvimento de estacas de Rhipsalis grandiflora Raw., compostas pelo artículo apical, tratadas com os fitorreguladores ácido indolbutírico (AIB) e ácido naftalenoacético (ANA), nas concentrações de 0, 4,07, 5,81 e $11,63 \mathrm{mmol} \mathrm{L}^{-1}$ do AIB e $0,4,53,6,47$ e $12,94 \mathrm{mmol} \mathrm{L}^{-1}$ do ANA. A base das estacas foi imersa na mistura de talco com as auxinas testadas, sendo colocadas em bandejas de poliestireno contendo casca de Pinus sp. e fibra de xaxim (1:1) e mantidas durante o período de enraizamento em casa de vegetação (50\% de sombra) com $60-90 \%$ de umidade relativa e temperatura na faixa de $20-25^{\circ} \mathrm{C}$. Foi empregado o delineamento inteiramente casualizado com oito tratamentos, amostragens aos $0,20,50,80$ e 150 dias e doze repetições. Não houve diferença entre os dois reguladores, na quantidade de massa seca de raízes produzida. As estacas cultivadas nos tratamentos 0 e 4,07 $\mathrm{mmol} \mathrm{L}^{-1}$ do AIB e $0,4,53 \mathrm{mmol} \mathrm{L}^{-1}$ do ANA apresentaram acúmulo de massa seca de raízes, quando comparado aos demais tratamentos. Nas estacas em que se aplicaram 4,07 $\mathrm{mmol}$ $\mathrm{L}^{-1}$ do AIB e 4,53 $\mathrm{mmol} \mathrm{L}^{-1}$ do ANA, a massa seca das brotações foi significativamente superior, em relação às estacas com $0 \mathrm{mmol} \mathrm{L}^{-1}$ de fitorregulador.

Palavras-chave: Rhipsalidinae, mudas, artículos, fitorreguladores
\end{abstract}

\section{INTRODUCTION}

The genus Rhipsalis is included in the CactaceaeRhipsalidinae family, and is represented mainly by epiphyitic species, and sometimes lithophytic, widely distributed within the Americas, with some species occurring in the tropical Africa and Indian Ocean islands
(Loefgren, 1915; Lombardi, 1991). Since Cactaceae are typically xerophytic, this group is specialized in surviving on trees in the humid tropical forests, in places with higher light intensity. Besides performing photosynthesis, their thickened stems store water and nutrients for their survival (Britton \& Rose, 1923; Joly, 1976; Scheinvar, 1985). 
The Christmas Cactus and the Easter Cactus of the genus Schlumbergera (=Zygocactus) are common flower crop, as well as some species of Rhipsalis, Hatiora and Lepismium of the same subfamily Rhipsalidinae. In spite of the commercial interest, little is known about their propagation and cultivation. In the genus Rhipsalis, during the evolution process, regardless of its leaf-like shape, the stem became photosynthetic tissue, and also became a storage organ: this modified stem is formed by segments called articles. Propagation techniques use vegetative portions of the plant, such as the stem, roots or leaves (Hartmann et al., 1997).

In addition to genetic factors, adventitious root formation on the stem also depends on the presence of substances in cells and buds, which can be auxins (Válio, 1979), carbohydrates, nitrogenous compounds, vitamins and other substances. Multiplication by cutting can be achieved with or without the use of plant growth regulators and the cutting has to be dipped in a substrate. When this propagation technique is used, light intensity and quality are very important factors for root formation as semi-hardwood and herbaceous cuttings root better in the presence of light (Hartmann et al., 1997).

The objective of this study was to determine the effect of exogenous application of plant growth regulators (auxins) on the induction and formation of root and shoot bud differentiation, by evaluating the dry mass produced, using the apical article of Rhipsalis grandiflora Haw. as stem cutting.

\section{MATERIAL AND METHODS}

The activity of indolebutyric acid IBA, at the concentrations of $0 ; 4.07 ; 5.81$, and $11.63 \mathrm{mmol} \mathrm{L}^{-1}$ and naphthaleneacetic acid and NAA, at $0 ; 4.53 ; 6.47$, and $12.94 \mathrm{mmol} \mathrm{L}^{-1}$ was evaluated separately. Talc was used in the preparation of the powdered mixtures with rooting regulators. The auxins were weighed separately, and the talc was added in small amounts until the desired concentration was achieved. This procedure enabled the homogenization of the powder.

Four hundred and eighty stem cuttings of the $R$. grandiflora were selected, consisting of only one apical article, their length ranging from 11.8 to $12.8 \mathrm{~cm}$, and their diameter, from 3 to $5 \mathrm{~mm}$. Before the powder was applied, about four cuts were made at the base of the stem cutting in order to stimulate root formation. The base of the stem cuttings was dipped into the mixture of talc and plant growth regulator, IBA or NAA, and then placed in polystyrene propagation flats containing forty-eight cells of 120 $\mathrm{mL}$ each. The substrate was a mixture of fir bark of Pinus sp. and fern fiber, in the proportion of 1 to 1 , and each stem cutting was inserted up to $1 / 3$ of its total length into individual cells. The flats were transferred to a greenhouse, with $50 \%$ shading, relative humidity at $60-90 \%$, tempera- ture ranging from 20 to $25^{\circ} \mathrm{C}$, and kept there until the end of the experiment. The frequency of watering was established according to the variation in the substrate moisture content, which was maintained between 100 and $70 \%$.

The experimental design was a completely randomized consisting of eight treatments, five sampling periods $(0 ; 20 ; 50 ; 80$, and 150 days), and twelve replicates. The mean tests were compared for each plant growth regulator and rate, as well as for each sampling period. During samplings, each plant was separated into roots, stem cutting and shoot bud differentiation. A ruler was used to measure the root length. After identification, the samples were dried at $80^{\circ} \mathrm{C}$ until constant weight. Data were analyzed by the Newman-Keuls test at $5 \%$.

\section{RESULTS AND DISCUSSION}

During the first 20 days, there was a reduction in the dry mass of the stem cuttings for all treatments (Figure 1, Table 1). From day 20 to day 80, stem cuttings of the control treatment, and those treated with 4.07 mmol L ${ }^{-1}$ of IBA, or $4.53 \mathrm{mmol} \mathrm{L}^{-1}$ of NAA had a larger accumulation of dry mass, reaching their maximum values at day 80, which corresponded to the dry mass observed at the beginning of the experiment. For these treatments, after that period and up to day 150 , the amount

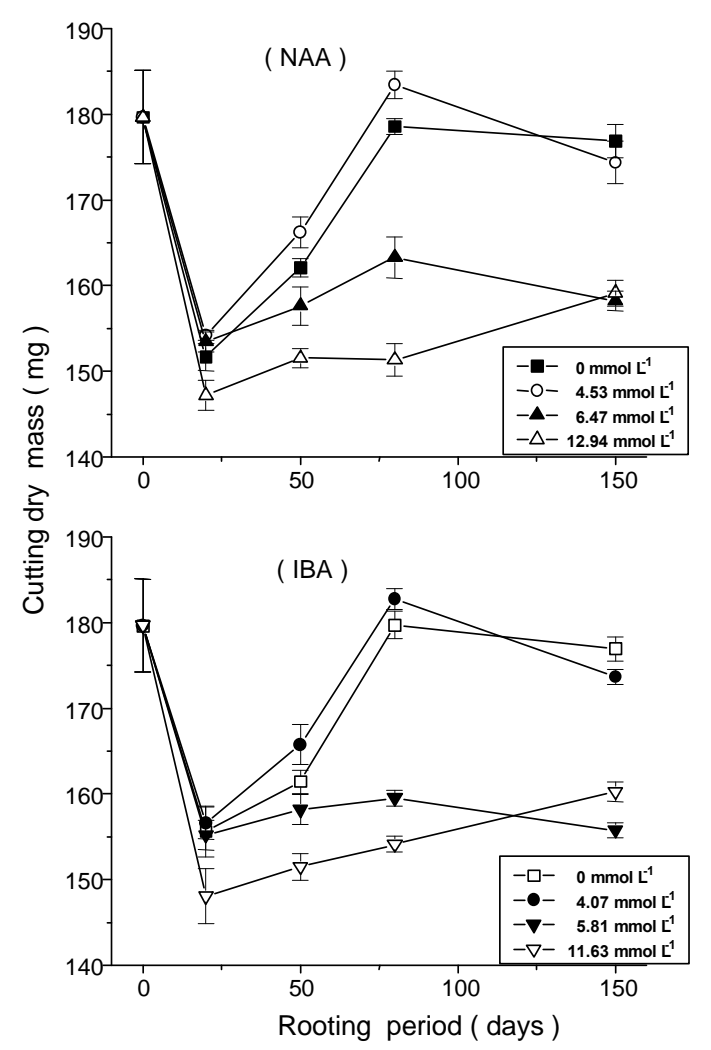

Figure 1 - Changes in the dry mass of Rhipsalis grandiflora Haw. (Cactaceae) cuttings treated with IBA at 0 , $4.07,5.81$ and $11.63 \mathrm{mmol} \mathrm{L}^{-1}$ and, NAA at $0,4.53$, 6.47 and $12.94 \mathrm{mmol} \mathrm{L}^{-1}$. 
of dry mass of the stem cuttings remained unchanged, or had a small decrease, and there was no difference between plant growth regulators. On the other hand, as for the first twenty days, stem cuttings treated with $5.81 \mathrm{mmol} \mathrm{L}^{-1}$, or $11.63 \mathrm{mmol} \mathrm{L}^{-1}$ of IBA, and with 6.47 , or 12.94 mmol L ${ }^{-1}$ of NAA recovered partially their initial dry mass, reaching $85-90 \%$ at the end of the experiment, which corresponds to a difference in relation to stem cuttings of the other treatments (Table 1). Even though the curve shown in Figure 2 does not represent the biological process, it was obtained by linear regression and reveals the gain of dry mass achieved at the last sampling, thus indicating that stem cuttings of the control, and those treated with $4.07 \mathrm{mmol} \mathrm{L}^{-1}$ of IBA, or $4.53 \mathrm{mmol} \mathrm{L}^{-1}$ of NAA, resumed their growth.
For all treatments, the root formation process initiated twenty days after the beginning of the experiment, coinciding with the smallest dry mass of the stem cuttings (Figures 1 and 3, and Table 2). On day 50, the control stem cuttings and those treated with $4.07 \mathrm{mmol} \mathrm{L}^{-1}$ of IBA, or $4.53 \mathrm{mmol} \mathrm{L}^{-1}$ of NAA began to present a higher increase in root weight as compared to stem cuttings treated with 5.81 and $11.63 \mathrm{mmol} \mathrm{L}^{-1}$ of IBA, or 6.47 and $12.94 \mathrm{mmol}$ $\mathrm{L}^{-1}$ of NAA. At the last sampling date, the dry mass of roots accumulated in the control stem cuttings was larger than in stem cuttings treated with $4.07 \mathrm{mmol} \mathrm{L}^{-1}$ of IBA, or 4.53 mmol L ${ }^{-1}$ of NAA (Table 2), which in turn was larger than that observed for stem cuttings treated with 11.63 mmol L $\mathrm{L}^{-1}$ of IBA, or $12.94 \mathrm{mmol} \mathrm{L}^{-1}$ of NAA, and for stem cuttings treated with $5.81 \mathrm{mmol} \mathrm{L}^{-1}$ of IBA, or

Table 1 - Mean values of dry mass of Rhipsalis grandiflora Haw. (Cactaceae) cutting, in $m g$, in those treated with IBA at 0 , 4.07, 5.81 and $11.63 \mathrm{mmol} \mathrm{L}^{-1}$ and, NAA at $0,4.53,6.47$ and $12.94 \mathrm{mmol} \mathrm{L}^{-1}$.

\begin{tabular}{|c|c|c|c|c|c|c|}
\hline \multirow{2}{*}{$\begin{array}{l}\text { Plant regulators/ } \\
\text { concentration }\end{array}$} & \multicolumn{6}{|c|}{ Rooting period } \\
\hline & 0 & 20 & 50 & 80 & 150 & Mean $^{1}$ \\
\hline $\mathrm{mmol} \mathrm{L}^{-1}$ & - & 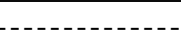 & 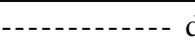 & 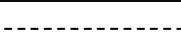 & - & 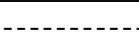 \\
\hline IBA 0 & $176.03 \mathrm{a}^{2}$ & $150.38 \mathrm{fgh}$ & $162.18 \mathrm{bcd}$ & $178.42 \mathrm{a}$ & $176.56 \mathrm{a}$ & $168.71 \mathrm{~A}$ \\
\hline IBA 4.07 & $176.03 \mathrm{a}$ & $149.96 \mathrm{fgh}$ & $165.18 \mathrm{bc}$ & $182.02 \mathrm{a}$ & $175.23 \mathrm{a}$ & $169.68 \mathrm{~A}$ \\
\hline IBA 5.81 & $176.03 \mathrm{a}$ & $149.47 \mathrm{fgh}$ & $156.48 \mathrm{cdef}$ & $160.85 \mathrm{bcd}$ & 158.44 cdef & $160.25 \mathrm{~B}$ \\
\hline IBA 11.63 & $176.03 \mathrm{a}$ & $144.96 \mathrm{~h}$ & 151.87 efgh & $154.20 \mathrm{defg}$ & $160.59 \mathrm{bcd}$ & $157.53 \mathrm{C}$ \\
\hline NAA 0 & $176.03 \mathrm{a}$ & 150.78 efgh & $162.82 \mathrm{bcd}$ & $179.05 \mathrm{a}$ & $178.57 \mathrm{a}$ & $169.45 \mathrm{~A}$ \\
\hline NAA 4.53 & $176.03 \mathrm{a}$ & 151.34 efgh & $166.06 \mathrm{~b}$ & $182.57 \mathrm{a}$ & $174.44 \mathrm{a}$ & $170.09 \mathrm{~A}$ \\
\hline NAA 6.47 & $176.03 \mathrm{a}$ & 150.75 efgh & $157.05 \mathrm{cdef}$ & $161.32 \mathrm{bcd}$ & 158.05 bcdef & $160.64 \mathrm{~B}$ \\
\hline NAA 12.94 & $176.03 \mathrm{a}$ & $146.03 \mathrm{gh}$ & $151.82 \mathrm{efgh}$ & $151.18 \mathrm{efgh}$ & 159.43 bcde & $156.90 \mathrm{C}$ \\
\hline Mean $^{1}$ & $176.03 \mathrm{~A}$ & $149.21 \mathrm{D}$ & $159.18 \mathrm{C}$ & $168.70 \mathrm{~B}$ & $167.66 \mathrm{~B}$ & 164.16 \\
\hline
\end{tabular}

$\mathrm{CV}(\%)=4.0 ; \mathrm{s}=6.51$

${ }^{1}$ Mean followed by the same upper case letter are not different by the Newman-Keuls test at $5 \%$.

${ }^{2}$ Mean followed by the same lower case letter are not different by the Newman-Keuls test at $5 \%$.

Table 2 - Mean values of the dry mass of roots, in $m g$, of Rhipsalis grandiflora Haw. (Cactaceae) cuttings treated with IBA at $0,4.07,5.81$ and $11.63 \mathrm{mmol} \mathrm{L}^{-1}$ and, NAA at $0,4.53,6.47$ and $12.94 \mathrm{mmol} \mathrm{L}^{-1}$.

\begin{tabular}{|c|c|c|c|c|c|c|}
\hline \multirow{2}{*}{$\begin{array}{l}\text { Plant regulators/ } \\
\text { concentration }\end{array}$} & \multicolumn{6}{|c|}{ Rooting period } \\
\hline & 0 & 20 & 50 & 80 & 150 & Mean $^{1}$ \\
\hline $\mathrm{mmol} \mathrm{L}^{-1}$ & - & - & $-\cdots$ & - & - & - \\
\hline IBA 0 & $0.00 \mathrm{k}^{2}$ & $11.97 \mathrm{j}$ & $21.13 \mathrm{~g}$ & $28.69 \mathrm{de}$ & $63.52 \mathrm{a}$ & $25.06 \mathrm{~A}$ \\
\hline IBA 4.07 & $0.00 \mathrm{k}$ & $11.73 \mathrm{j}$ & $21.21 \mathrm{~g}$ & $26.83 \mathrm{f}$ & $60.89 \mathrm{~b}$ & $24.13 \mathrm{~B}$ \\
\hline IBA 5.81 & $0.00 \mathrm{k}$ & $11.62 \mathrm{j}$ & $14.37 \mathrm{i}$ & $17.89 \mathrm{~h}$ & $29.31 \mathrm{~d}$ & $14.64 \mathrm{C}$ \\
\hline IBA 11.63 & $0.00 \mathrm{k}$ & $11.49 \mathrm{j}$ & $12.02 \mathrm{j}$ & $18.17 \mathrm{~h}$ & $31.24 \mathrm{c}$ & $14.58 \mathrm{C}$ \\
\hline NAA 0 & $0.00 \mathrm{k}$ & $11.72 \mathrm{j}$ & $21.19 \mathrm{~g}$ & $28.56 \mathrm{e}$ & $63.34 \mathrm{a}$ & $24.96 \mathrm{~A}$ \\
\hline NAA 4.53 & $0.00 \mathrm{k}$ & $11.78 \mathrm{j}$ & $21.23 \mathrm{~g}$ & $26.61 \mathrm{f}$ & $60.88 \mathrm{~b}$ & $24.10 \mathrm{~B}$ \\
\hline NAA 6.47 & $0.00 \mathrm{k}$ & $11.59 \mathrm{j}$ & $14.27 \mathrm{i}$ & $17.67 \mathrm{~h}$ & $29.17 \mathrm{de}$ & $14.54 \mathrm{C}$ \\
\hline NAA 12.94 & $0.00 \mathrm{k}$ & $11.47 \mathrm{j}$ & $12.08 \mathrm{j}$ & $18.03 \mathrm{~h}$ & $30.78 \mathrm{c}$ & $14.47 \mathrm{C}$ \\
\hline Mean $^{1}$ & $0.00 \mathrm{E}$ & $11.67 \mathrm{D}$ & $17.19 \mathrm{C}$ & $22.81 \mathrm{~B}$ & $46.14 \mathrm{~A}$ & \\
\hline
\end{tabular}

$\mathrm{CV}(\%)=3.4 ; \mathrm{s}=0.66$

${ }^{1}$ Mean followed by the same upper case letter are not different by the Newman-Keuls test at $5 \%$.

${ }^{2}$ Mean followed by the same lower case letter are not different by the Newman-Keuls test at $5 \%$. 


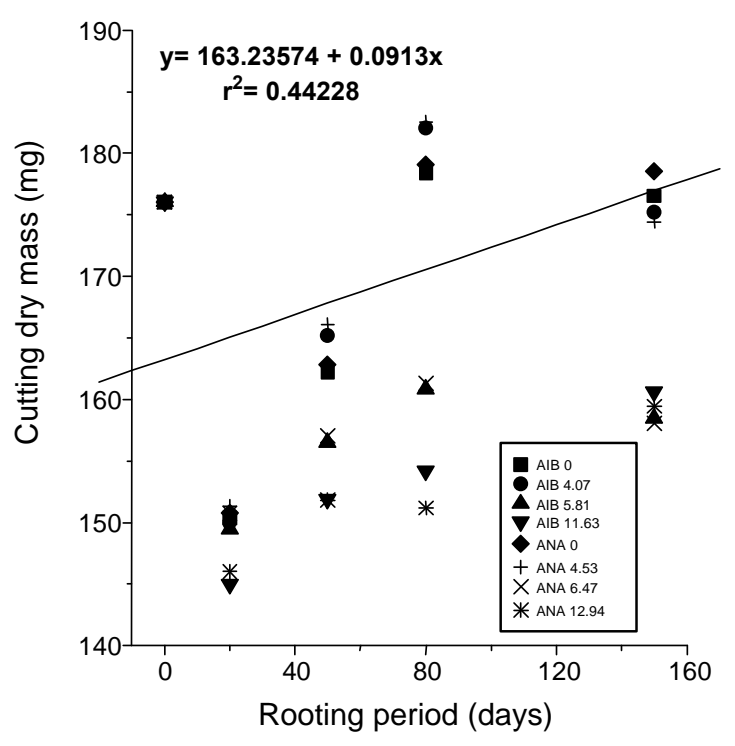

Figure 2 - Linear regression for Rhipsalis grandiflora Haw. (Cactaceae) dry mass of cuttings, in those treated with IBA at $0,4.07,5.81$ and $11.63 \mathrm{mmol} \mathrm{L}^{-1}$ and, NAA at 0, 4.53, 6.47 and $12.94 \mathrm{mmol} \mathrm{L}^{-1}$.

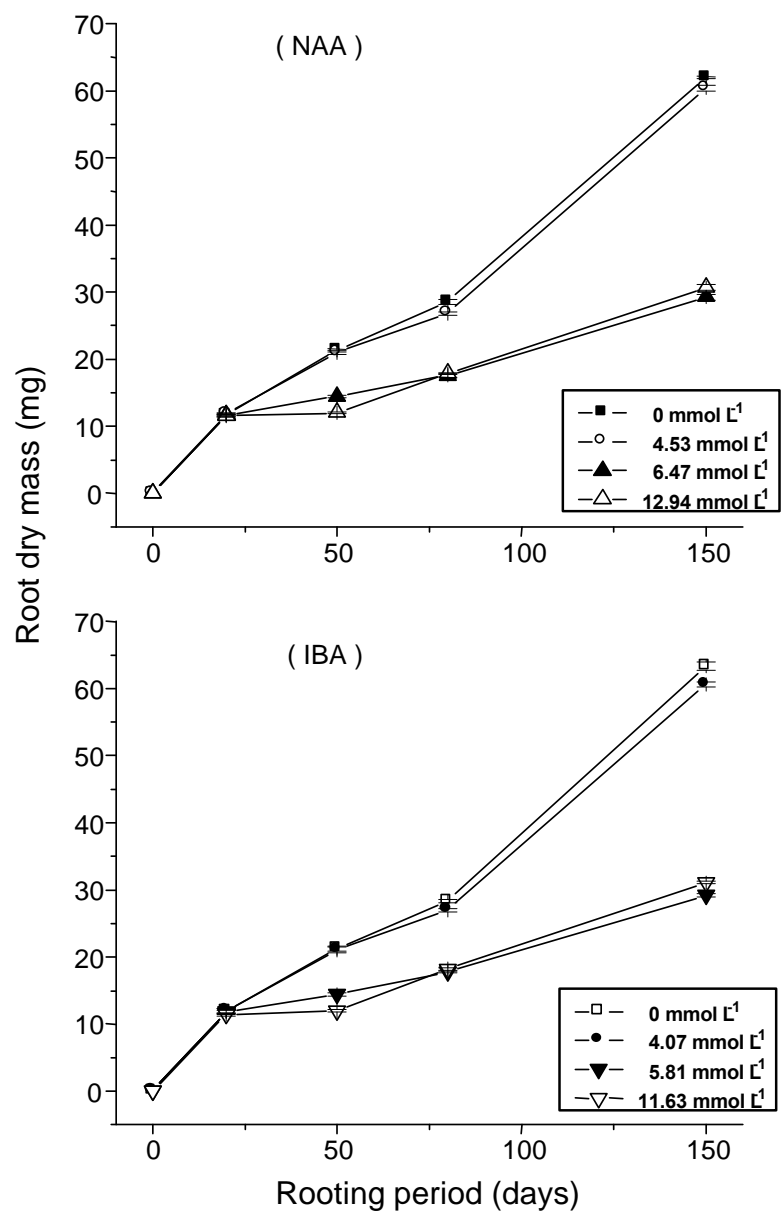

Figure 3 - Accumulation of dry mass of roots, of Rhipsalis grandiflora Haw. (Cactaceae) cuttings treated with IBA at $0,4.07,5.81$ and $11.63 \mathrm{mmol} \mathrm{L}^{-1}$ and, NAA at 0 , 4.53, 6.47 and $12.94 \mathrm{mmol} \mathrm{L}^{-1}$.
$6.47 \mathrm{mmol} \mathrm{L}^{-1}$ of NAA. Stem cuttings treated with 5.81 and $11.63 \mathrm{mmol} \mathrm{L}^{-1}$ of IBA, or 6.47 and $12.94 \mathrm{mmol} \mathrm{L}^{-1}$ of NAA, accumulated nearly $46-48 \%$ of dry mass of roots compared to those treated with $4.07 \mathrm{mmol} \mathrm{L^{-1 }}$ of IBA, or $4.53 \mathrm{mmol} \mathrm{L}^{-1}$ of NAA, or in relation to the control stem cuttings, indicating that higher concentrations of auxins affected negatively the accumulation of root dry mass. For each concentration, there were no differences among the effects of the plant growth regulators, as the regression curve obtained from the dry mass values shows a constant root increase rate, which actually occurred for the control stem cuttings, $4.07 \mathrm{mmol} \mathrm{L}^{-1}$ of IBA, and $4.53 \mathrm{mmol} \mathrm{L}^{-1}$ of NAA (Figure 4).

Stem cuttings treated with $4.07 \mathrm{mmol} \mathrm{L}^{-1}$ of IBA and $4.53 \mathrm{mmol} \mathrm{L}^{-1}$ of NAA were the ones that had the largest accumulation of dry mass of shoot bud differentiation, followed by stem cuttings in the control treatment, having an accumulation of shoot bud differentiation about $40 \%$ smaller (Figure 5 and Table 3). The dry mass of shoot bud differentiation for stem cuttings treated with 5.81 and $11.63 \mathrm{mmol} \mathrm{L}^{-1} \mathrm{IBA}$, or 6.47 and 12.94 mmol L $\mathrm{L}^{-1} \mathrm{NAA}$ is, on the average, $38 \%$ of that treated with $4.07 \mathrm{mmol} \mathrm{L}^{-1}$ of IBA, or $4,53 \mathrm{mmol} \mathrm{L}^{-1}$ of NAA. Accumulation of dry mass in the shoot bud differentiation for stem cuttings treated with $4.07 \mathrm{mmol} \mathrm{L}^{-1}$ of IBA, or $4.53 \mathrm{mmol} \mathrm{L}^{-1}$ of NAA was more noticeable in the last period of the experiment, that is, from day 80 to day 150 (Figure 5 and Table 3). Regarding the dry mass of shoot bud differentiation, stem cuttings of the control and those treated with IBA 4.07 and NAA 4.53 (Figure 6), tend towards accumulation. Comparatively, stem cuttings of the other treatments, 5.81 and $11.63 \mathrm{mmol} \mathrm{L}^{-1}$ of IBA, or 6.47 and $12.94 \mathrm{mmol} \mathrm{L}^{-1}$ of NAA showed smaller accumulation of dry mass of shoot bud differentiation.

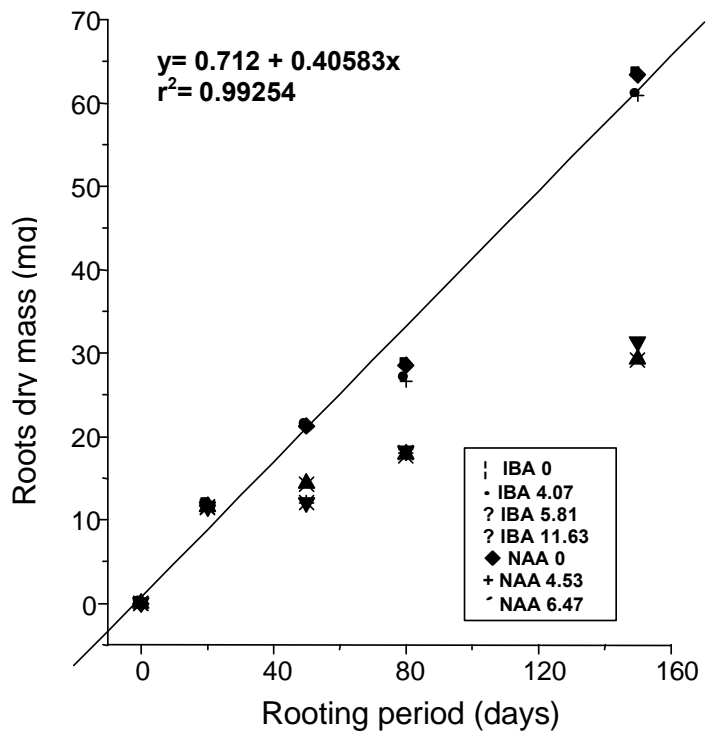

Figure 4 - Linear regression tor dry mass of roots, in Rhipsalis grandiflora Haw. (Cactaceae) cuttings treated with IBA at $0,4.07,5.81$ and $11.63 \mathrm{mmol} \mathrm{L}^{-1}$ and, NAA at 0 , 4.53, 6.47 and $12.94 \mathrm{mmol} \mathrm{L}^{-1}$. 
Table 3 - Means values of shoot bud differentiation, in $m g$, of Rhipsalis grandiflora Haw. (Cactaceae) cuttings treated with IBA at $0,4.07,5.81$ and $11.63 \mathrm{mmol} \mathrm{L}^{-1}$ and, NAA at $0,4.53,6.47$ and $12.94 \mathrm{mmol} \mathrm{L}^{-1}$.

\begin{tabular}{|c|c|c|c|c|c|c|}
\hline \multirow{2}{*}{$\begin{array}{l}\text { Plant regulators/ } \\
\text { concentration }\end{array}$} & \multicolumn{6}{|c|}{ Rooting period } \\
\hline & 0 & 20 & 50 & 80 & 150 & Mean $^{1}$ \\
\hline $\mathrm{mmol} \mathrm{L} \mathrm{L}^{-1}$ & - & - - & - & - & - - - & 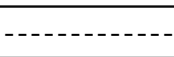 \\
\hline IBA 0 & $0.00 \mathrm{t}^{2}$ & $0.00 \mathrm{t}$ & $31.13 \mathrm{p}$ & 82.26 hi & $135.93 \mathrm{c}$ & $49.86 \mathrm{C}$ \\
\hline IBA 4.07 & $0.00 \mathrm{t}$ & $0.00 \mathrm{t}$ & $36.07 \mathrm{o}$ & $121.00 \mathrm{e}$ & $229.92 \mathrm{a}$ & $77.40 \mathrm{~A}$ \\
\hline IBA 5.81 & $0.00 \mathrm{t}$ & $0.00 \mathrm{t}$ & $25.35 \mathrm{r}$ & 58.071 & $84.64 \mathrm{~g}$ & $33.61 \mathrm{E}$ \\
\hline IBA 11.63 & $0.00 \mathrm{t}$ & $0.00 \mathrm{t}$ & $20.97 \mathrm{~s}$ & $52.66 \mathrm{n}$ & $80.82 \mathrm{ij}$ & $30.89 \mathrm{G}$ \\
\hline NAA 0 & $0.00 \mathrm{t}$ & $0.00 \mathrm{t}$ & $29.48 \mathrm{q}$ & $80.11 \mathrm{j}$ & $122.50 \mathrm{~d}$ & $46.42 \mathrm{D}$ \\
\hline NAA 4.53 & $0.00 \mathrm{t}$ & $0.00 \mathrm{t}$ & $37.39 \mathrm{o}$ & $115.10 \mathrm{f}$ & $201.67 \mathrm{~b}$ & $70.83 \mathrm{~B}$ \\
\hline NAA 6.47 & $0.00 \mathrm{t}$ & $0.00 \mathrm{t}$ & $24.72 \mathrm{r}$ & $60.47 \mathrm{k}$ & $79.97 \mathrm{j}$ & $33.03 \mathrm{E}$ \\
\hline NAA 12.94 & $0.00 \mathrm{t}$ & $0.00 \mathrm{t}$ & $22.03 \mathrm{~s}$ & $55.27 \mathrm{~m}$ & $83.17 \mathrm{~h}$ & $32.10 \mathrm{~F}$ \\
\hline Mean $^{1}$ & $0.00 \mathrm{D}$ & $0.00 \mathrm{D}$ & $28.39 \mathrm{C}$ & $78.12 \mathrm{~B}$ & $127.33 \mathrm{~A}$ & \\
\hline
\end{tabular}

$\mathrm{CV}(\%)=3.8 ; \mathrm{s}=1.79$

${ }^{1}$ Mean followed by the same upper case letter are not different by the Newman-Keuls test at $5 \%$.

${ }^{2}$ Mean followed by the same lower case letter are not different by the Newman-Keuls test at $5 \%$

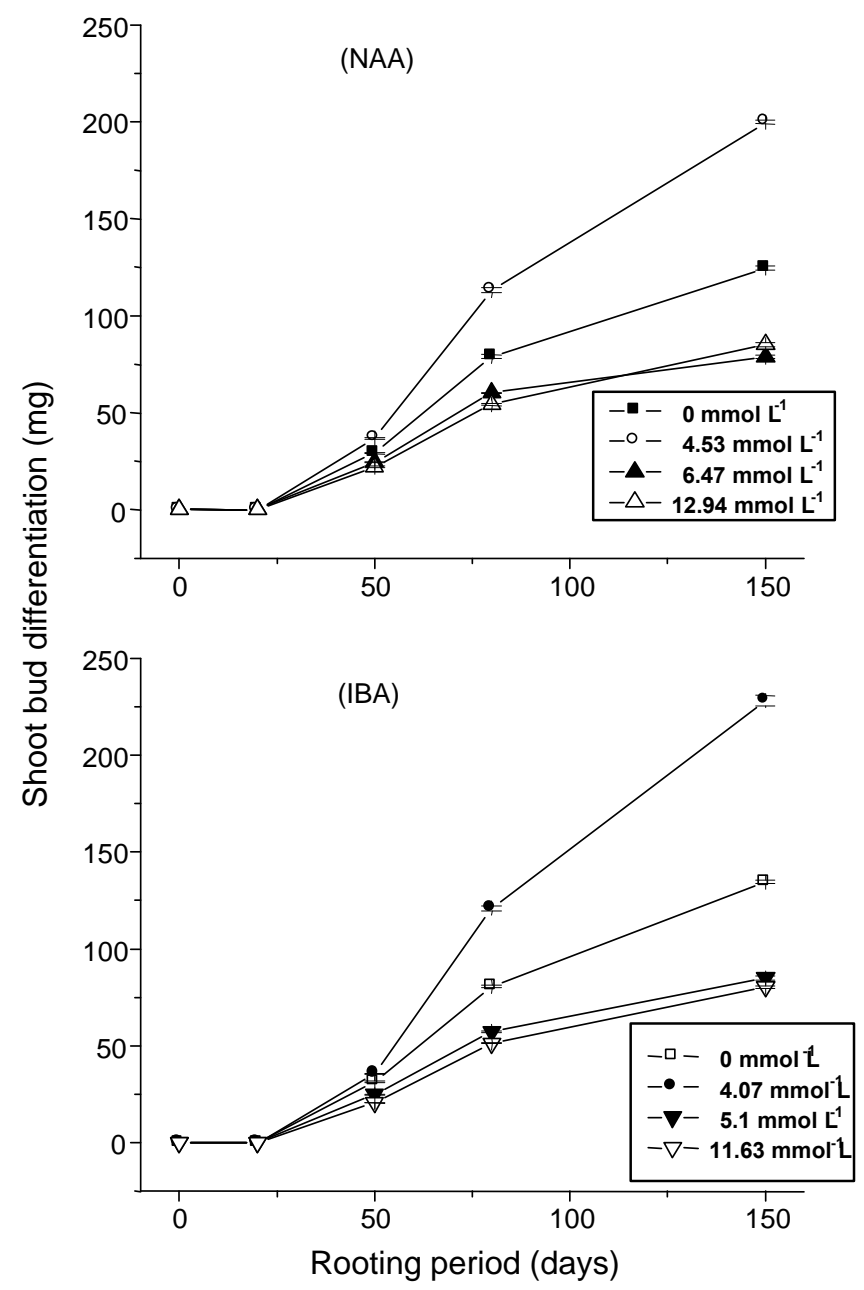

Figure 5 - Accumulation of shoot bud differentiation dry mass, of Rhipsalis grandiflora Haw. (Cactaceae) cuttings treated with IBA at $0,4.07,5.81$ and $11.63 \mathrm{mmol} \mathrm{L}^{-1}$ and, NAA at $0,4.53,6.47$ and $12.94 \mathrm{mmol} \mathrm{L}^{-1}$.

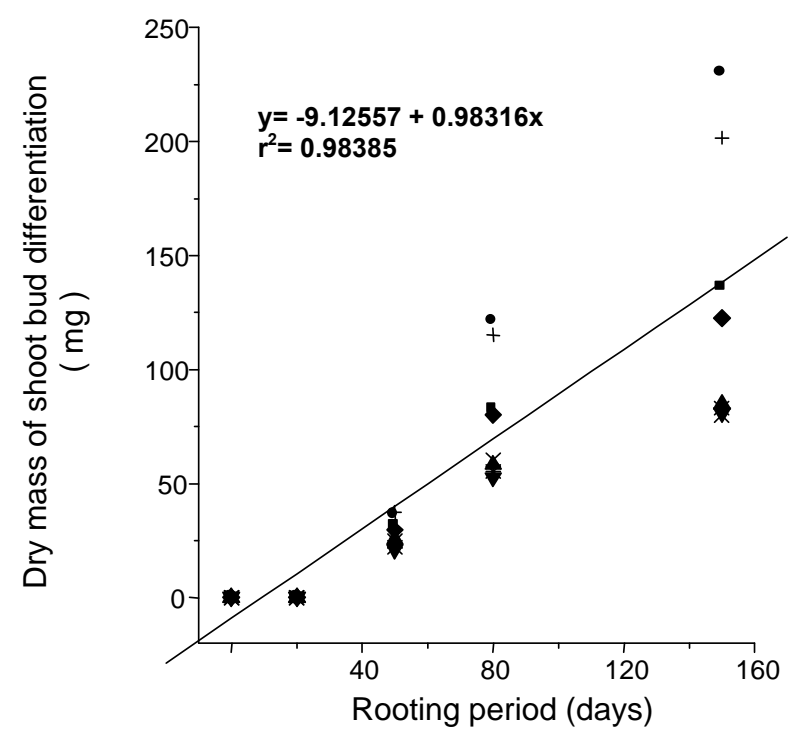

Figure 6 - Linear regression for dry mass of shoot bud differentiation, of Rhipsalis grandiflora Haw. (Cactaceae) cuttings treated with IBA at $0,4.07,5.81$ and $11.63 \mathrm{mmol} \mathrm{L}^{-1}$.

Both plant growth regulators showed similar activities in promoting root system formation and shoot bud differentiation growth (Figures 1, 2, 3, 4, 5, and 6, and Tables 1, 2, and 3). Apparently, R. grandiflora stem cuttings have an adequate endogenous level of auxin for initiating root formation, since the stem cuttings that were not treated with the plant growth regulators developed satisfactorily.

In relation to metabolic changes that occurred in stem cuttings, formation of the root system was initiated only after they had a decrease in dry mass, for all treatments. Thus, once they were separated from the stock plant, and kept in proper growth conditions, the stem cuttings would 
have part of their reserves hydrolysed, probably starch and/ or other storage carbohydrates, to form roots. This is supported by studies carried out by Stuart (1938), Molnar \& LaCroix (1972), and Breen \& Muraoka (1974), which indicate that the hydrolysis of starch stored in the cutting is stimulated as root formation starts. Therefore, the hydrolysis of carbohydrates in the cutting would be important during the rooting process, in order to supply intermediate compounds as source of energy and carbon skeletons.

Opposite to the observations of Stuart (1938), Molnar \& LaCroix (1972), Cuquel et al. (1992), Cuquel \& Minami (1994), and Tofanelli et al. (2002), the exogenous application of auxin inhibited the accumulation of dry mass in the roots, as stem cuttings for control treatment presented a larger amount (Figure 3 and Table 2). Similar results were obtained by Prati et al. (1999), indicating that the application of IBA or NAA does not promote rooting in semi-hardwood cuttings of 'Tahiti' lime (Citrus latifolia Tanaka). On the other hand, application of $4.07 \mathrm{mmol} \mathrm{L}^{-1}$ of IBA, or $4.53 \mathrm{mmol} \mathrm{L}^{-1}$ of NAA stimulated the accumulation of dry mass in shoot bud differentiation, which was probably the result of an increase in the metabolic activity in stem cuttings and greater flow of metabolites to the growing shoot bud differentiation (Figure 5 and Table 3), an information that agrees with Breen \& Muraoka (1973) and Davis \& Haissig (1990), who detected an increase in the sink activity of shoot bud differentiation and a higher hydrolysis rate for carbohydrates stored in cuttings treated with IBA.

Sprouting of the aerial part occurred only 50 days after the initial sampling (Figure 5), at the time when the incorporation of the dry mass in stem cuttings was initiated (Figure 1), and they already had roots (Figure 3 ). As for day 80 , when stem cuttings of the control and those treated with $4.07 \mathrm{mmol} \mathrm{L}^{-1}$ of IBA, or $4.53 \mathrm{mmol} \mathrm{L}^{-1}$ of NAA recovered the dry mass of the beginning of the experiment, the accumulation rate of dry mass in root and shoot bud differentiation increased, yielding more roots and aerial part. Therefore, for the production of $R$. grandiflora from stem cuttings, the exogenous application of auxin, IBA at $4.07 \mathrm{mmol} \mathrm{L}^{-1}$, or NAA at $4.53 \mathrm{mmol} \mathrm{L}^{-1}$ did not promote increase in roots directly, but the shoot bud differentiation, when compared to the production of plants without the application of auxins for rooting.

Application of auxin did not affect root length, its maximum value ranging from 14 to $15 \mathrm{~cm}$ in the concentrations used in our experiments. On the other hand, an opposite result was obtained by Mayer et al. (2001), who found that IBA stimulated the emission of roots and increased the length in the propagation of Prunnus mume Sieb \& Zucc. from herbaceous cuttings. Thus, for $R$. grandiflora, genetic component play a main role in rooting, acting independently of the applications of plant growth regulators. Plant production of $R$. grandiflora can be achieved from mature apical articles, which seem to have the proper levels of auxins. Besides being expensive, high rates of plant growth regulators are unnecessary, and may even be harmful for the development of cuttings.

\section{ACKNOWLEDGEMENTS}

To Dr. Antonio Luís Gonçalves (in memorian), fellow and friend and one of the scientists who started the work with ornamental epiphytes from the family Cactaceae in Brazil. Authors thank Dr. Oliveiro Guerreiro Filho for the suggestions in statistical analysis and Dr. Marcos Silveira Buckeridge for the help in the english version.

\section{REFERENCES}

BREEN, P.J.; MURAOKA, T. Effect of indolebutyric acid on distribuiton of ${ }^{14} \mathrm{C}$-photosynthate in softwood cuttings of 'Mariana 2624' Plum. Journal of the American Society for Horticultural Science, v.98, p.436-439, 1973

BREEN, P.J.; MURAOKA, T. Effect of leaves on carbohydrate content and movement of ${ }^{14} \mathrm{C}$-assimilate in Plum cuttings. Journal of the American Society for Horticultural Science, v.99, p.326-332, 1974

BRITTON, N.; ROSE, J.N. The Cactaceae. Washington: Carnegie Institute 1923. v.4, 325p.

CUQUEL, F.L.; MINAMI, K. Enraizamento de estacas de crisântemo [Dendranthema morifolium (RAMAT.) TZVELEV] tratadas com ácido indolbutírico veiculado em talco. Scientia Agricola, v.51, p.28-35, 1994.

CUQUEL, F.L.; GRANJA, N.P.; MINAMI, K. Avaliação do enraizamento de estacas de crisântemo (Chrysanthemum morifolium L.) cv. White Reagan 606 tratadas com ácido indolbutírico (IBA). Scientia Agricola, v.49, p.15-22, 1992.

DAVIS, T.D.; HAISSIG, B.E. Chemical control of adventitious roo formation in cuttings. Plant Growth Regulation, v.18, p.1-17, 1990.

HARTMANN, H.T.; KESTER, D.E.; DAVIES JR., F.T.; GENEVE, R.L. Plant propagation: principles and practices. 6.ed. Upper Saddle River: Prentice-Hall, 1997. 770p

JOLY, A.B. Botânica: Introdução à taxonomia vegetal. 3.ed. São Paulo: Editora Nacional, 1976. 778p.

LOEFGREN, A. O gênero Rhipsalis. Arquivos do Jardim Botânico do Rio de Janeiro, v.1, p.59-104, 1915

LOMBARDI, J.A. O gênero Rhipsalis Gärtner (Cactaceae), no estado de São Paulo - 1. Espécies com ramos cilíndricos ou sub-cilíndricos. Acta Botanica Brasilica, v.5, p.53-76, 1991.

MAYER, N.A.; PEREIRA, F.M.; NACHTIGAL, J.C. Propagação do umezeiro (Prunnus mume Sieb \& Zucc.) por estaquia herbácea. Revista Brasileira de Fruticultura, v.23, p.643-646, 2001

MOLNAR, J.M.; LACROIX, L.J. Studies of the rooting of cuttings of Hydrangea macrophylla: enzime changes. Canadian Journal of Botany, v.50, p.315-322, 1972 .

PRATI, P.; MOURÃO FILHO, F.A.A.; DIAS, C.T.S.; SCARPARE FILHO, J.A. Estaquia semi-lenhosa: um método rápido e alternativo para a produção de mudas de lima ácida "Tahiti”. Scientia Agricola, v.56, p.185-190, 1999

SCHEINVAR, L. Cactaceae. In: REITZ, R. (Ed.) Flora ilustrada catarinense. Itajaí: CNPq; IBDF, 1985. pt.1, p.1-383.

STUART, N.W. Nitrogen and carbohydrate metabolism of kidney bean cuttings as affected by treatment with indoleacetic acid. Botanical Gazette, v.100, p.298-311, 1938

TOFANELLI, M.B.D.; CHALFUN, N.N.J.; HOFFMANN, A.; CHALFUN JR., A. Efeito do ácido indolbutírico no enraizamento de estacas de ramos semi-lenhosos de pessegueiro. Pesquisa Agropecuária Brasileira, v.37, p.939-944, 2002

VÁLIO, I.F.M. Auxinas. In: FERRI, M.G. (Ed.) Fisiologia vegetal. São Paulo: Editora Pedagógica e Universitária Ltda, 1979. v.2, cap.2, p.39-70.

Received October 22, 2002

Accepted August 26, 2003 